\title{
Electrical conductivity of different common bean seeds genotypes ${ }^{1}$
}

\author{
Sibelle Santanna da Silva ${ }^{2 *}$, Roberval Daiton Vieira ${ }^{3}$, Camila Ribeiro de Souza \\ Grzybowski², Tereza Cristina de Carvalho², Maristela Panobianco $^{2}$
}

\begin{abstract}
The electrical conductivity test is a fast and non-subjective method used to assess seed physiological potential. Thus, the objective of this study was adapting the methodology for conducting the electrical conductivity test in common bean seeds and investigate effects of genotype in results of the test, comparing cultivars of the two trade groups: Carioca and Black. The study was conducted in two phases: 1 - tests with combinations of different temperatures $\left(20,25,30\right.$, and $\left.35^{\circ} \mathrm{C}\right)$ and five different inhibition periods $(4,8,16,20$ and $24 \mathrm{~h}$ ); and 2- assessment of influence of genotype by comparing results obtained on the seeds of both groups. Tests of accelerated aging and seedling emergence in field were also performed. It was concluded that, for seeds of common beans, electrical conductivity test may be performed with samples of 50 seeds per replication, soaked into $75 \mathrm{~mL}$ deionized water, incubated at $25^{\circ} \mathrm{C}$, and performing reading of results after 20 or $24 \mathrm{~h}$. It was also concluded that test efficiency is variable according to genotype, and that for the trade group Carioca, there is not genotype effect; although the same results have not occurred for results obtained for the trade group Black.
\end{abstract}

Index terms: Phaseolus vulgaris, vigor, leaching.

\section{Condutividade elétrica de sementes de diferentes genótipos de feijão}

RESUMO - O teste de condutividade elétrica é um método rápido e não subjetivo empregado na avaliação do potencial fisiológico de sementes. O objetivo deste trabalho foi adequar a metodologia para a condução do teste de condutividade elétrica em sementes de feijão, bem como investigar o efeito de genótipo nos resultados do teste, comparando cultivares de dois grupos comerciais: carioca e preto. A pesquisa foi conduzida em duas etapas: 1- testes com diferentes combinações de temperatura $\left(20,25,30\right.$ e $\left.35^{\circ} \mathrm{C}\right)$ e período de embebição (4, 8, 16, 20 e 24 horas); e 2 - avaliação da influência do genótipo, comparando as sementes das cultivares dos dois grupos comerciais. Também foram conduzidos testes de envelhecimento acelerado e emergência de plântulas no campo. Concluise que, para sementes de feijão, o teste de condutividade elétrica pode ser conduzido com 50 sementes por repetição, embebidas em $75 \mathrm{~mL}$ de água deionizada, incubadas a $25^{\circ} \mathrm{C}$, com leitura após 20 ou 24 horas. Também se concluiu que a eficiência do teste é variável de acordo com o genótipo, e que, para o grupo comercial carioca, não há efeito de genótipo; embora o mesmo não tenha ocorrido para os resultados obtidos para o grupo comercial preto.

Termos para indexação: Phaseolus vulgaris, vigor, lixiviação.

\section{Introduction}

The electrical conductivity test is a simple, fast, and inexpensive alternative used to estimate seed vigor and can be used as a good uniformity indicator of the seedling emergence in field for different plant species, such as: soybean Glycine $\max ($ L.) Merr. (Vieira et al., 2004); Bell pepper (Capsicum annuum L.) (Oliveira and Novembre, 2005); cowpea [Vigna unguiculata (L.) Walp.] (Dutra et al., 2006); pumpkin (Cucurbita pepo L.) (Vieira and Dutra, 2006); Black oat

${ }^{1}$ Submitted on $08 / 13 / 2012$. Accepted for publication on 10/19/2012. ${ }^{2}$ Setor de Ciências Agrárias, Universidade Federal do Paraná, 80035-050, Curitiba, PR, Brasil.
(Avena strigosa Schreb) (Menezes et al., 2007); castor bean (Ricinus communis L.) (Souza et al., 2009); Mung bean (Vigna radiata L.) (Araújo et al., 2011); and field pea [Pisum sativum var. arvense (L.) Poir] (Machado et al., 2011). The test is based on integrity of cellular membranes, once assesses the changes occurring in seed metabolism, through the amount of electrolytes released to the imbibition solution (leachates) (Vieira and Krzyzanowski, 1999).

Nevertheless, some factors inherent to methodology of this test are able to affect its results, such as: amount of moisture

\footnotetext{
${ }^{3}$ Departamento de Produção Vegetal, Universidade Estadual Paulista 14884-900 - Jaboticabal, SP, Brasil.

*Corresponding author < sibelless@gmail.com>
} 
(Dutra and Vieira, 2006; Soares et al., 2010); temperature, as well as imbibition periods (Dutra and Vieira, 2006; Carvalho et al., 2009a); number of seeds (Vidigal et al., 2008; Lopes et al., 2012); and the initial moisture content of seeds (Vieira et al., 2002; Barbosa et al., 2012).

In the literature, there are several studies indicating use of the test of electrical conductivity to assess vigor of common bean seeds (Phaseolus vulgaris L.) (Santos et al., 2003; 2004 and 2005; Botelho et al., 2010; Coelho et al., 2010), but using the same methodology recommended to assess soybean seeds (Hampton and TeKrony, 1995; Vieira and Krzyzanowski, 1999). Therefore, further studies are needed aiming at determining a specific methodology for this species.

In addition, there are indications that genotype might affect electrical conductivity test results on common bean seeds. In a study with several cultivars and lines of common beans, each represented by one single seed lot, Vieira et al. (1996) have found that some genotypes with high performance, when assessed by the tests of germination and accelerated aging, were sorted as low quality by the electrical conductivity test; although these authors have also found opposite results. Therefore, more detailed and careful studies on behavior of different commercial groups of common bean cultivars are needed; once that the genotypes of this species are sorted in several categories for commercialization.

In this study, the main objective was to adapt the methodology aiming at the suitable conduction of electrical conductivity test on common bean seeds and, thereafter, investigating influence of genotypes of this species in results of this test, by comparing two distinct commercial cultivars belonging to the trade groups: Carioca and Black.

This study has been carried out in two distinct phases according to the methodologies following described:

\section{Phase I}

During this phase, the experiments have been conducted in the laboratory of seed analyses of Department of Plant Sciences and Plant Health of the Federal University of Paraná, headquartered in the municipality of Curitiba, State of Paraná, Southern Brazil. The studies for determining the suitable methodology to the electrical conductivity test with common bean seeds were conducted with four different lots of seeds of the cultivar IPR Tuiuiú, which were produced in the harvest season of 2010/2011. To this, the seeds were submitted to different determinations, as following described:

Moisture content: this variable was assessed by the oven method, at $105 \pm 3{ }^{\circ} \mathrm{C}$, during $24 \mathrm{~h}$ (Brasil, 2009) by using two subsamples of $5.0 \mathrm{~g}$ seeds each, per each seed lot. Results were expressed in percentage of moisture content (wet basis);
Germination test: for this test, a sample of 200 seeds was split in eight subsamples of 25 seeds each. The seeds of each subsample were evenly distributed on top of two sheets of paper towel previously moistened with distilled water, in a volume equivalent to 2.5 times the mass of dry substrate, covered with another sheet of same paper likewise moistened, which were then made into rolls. Immediately after, these rolls were placed into a seed germinator (Brand Mangelsdorf $\left.{ }^{\circledR}\right)$ and kept at $25{ }^{\circ} \mathrm{C}$. The counting of emerged seedling was performed at the fifth day after sowing, by computing the percentage of normal seedlings emerged in each subsample (Brasil, 2009);

Accelerated aging test: for this test, a sample about 220 seeds. These seeds were then evenly distributed in a single layer upon a stainless screen, firmly fixed to the upper edge of plastic germination transparent boxes (Gerbox) measuring $11 \mathrm{~cm} \times 11 \mathrm{~cm} \times 3.5 \mathrm{~cm}$, containing $40 \mathrm{~mL}$ of water at the bottom, thus forming a moist chamber. Immediately after, the Gerboxes were lidded and then kept into a germination chamber, at constant temperature of $41^{\circ} \mathrm{C}$, during $72 \mathrm{~h}$ (Hampton and TeKrony, 1995). After this aging period, the seeds were subjected to germination test, according to procedures already described in previous item. The moisture content was determined before and after the accelerated aging test;

Seedling emergence in field: this test has been performed in seedbeds installed in the experimental area of the Department of Plant Sciences and Plant Health of the Agrarian Sciences Sector of the Federal University of Paraná, in November, 2011. To this, were used four subsamples of 100 seeds each, per lot. The seeds were manually sown in rows of $1.0 \mathrm{~m}$ long and approximately $3 \mathrm{~cm}$ deep. Irrigations were performed whenever needed, according to rainfall intensity during test conduction; this way assuring ideal water supply for germination of the seeds and emergence of seedlings. The assessment was carried out at the day fourteenth after sowing and results were expressed as the percentage;

Electrical conductivity test: through this test, it was studied the interaction between four different temperatures $\left(20,25,30\right.$ and $\left.35^{\circ} \mathrm{C}\right)$ and five different periods of seed imbibition (4, 8, 16, 20, and $24 \mathrm{~h}$ ) aiming at determining the best combination of temperature $\mathrm{x}$ imbibition period to be used specifically for common bean seeds. This way, four subsamples physically pure of 50 seeds each were used for each seed lot. The seeds were weighed in an analytical balance with $0.01 \mathrm{~g}$ precision and placed to soaking in plastic cups (180 mL capacity) containing $75 \mathrm{~mL}$ deionized water, which then were kept into a germination chamber under the previously determined temperatures. After each imbibition period (conditioning), the electrical conductivity of imbibition 
solution was determined by reading the values obtained, with aid of a digital conductivimeter. Results were expressed as $\mu \mathrm{S} . \mathrm{cm}^{-1} \cdot \mathrm{g}^{-1}$ seed.

\section{Phase II}

After determining the best interaction between suitable temperature and the ideal imbibition period for conducting the electrical conductivity test with seeds of common beans, the effect of genotype on this test results also has been assessed.

To this phase of research, were used two common beans cultivars from the trade group Carioca (cv. IPR 139 and cv. IPR Juriti) and two cultivars from the trade group Black (cv. IPR Gralha and cv. BRS Campeiro); each group represented by four different seed lots. All seeds used during this phase were also subjected to determination of moisture content and to tests of: germination; accelerated aging; and seedling emergence in field, using the same methodology previously described. Nevertheless, for the test of electrical conductivity, was utilized only the combination $25^{\circ} \mathrm{C}$ x $24 \mathrm{~h}$ of imbibition; and this combination was assessed with four replications of 50 seeds each, to each cultivar.

To this phase of research, a completely randomized experimental design was used with four replications per treatment and ANOVA has been separately computed for each genotype; except for data on moisture content. Means were compared by the Tukey test, at $1 \%$ probability.

\section{Results and Discussion}

\section{Phase I-definition of specific methodology for common bean seeds}

For all four seed lots assessed, data on initial moisture content of seeds for cv. IPR Tuiuiú were similar, with a maximum variation of 0.8 percentage points (Table 1). As emphasized by Marcos-Filho (2005), the knowledge of the initial moisture content of seeds is a very important aspect for obtaining reliable results, when the procedures are aimed at standardizing methodology for the electrical conductivity test.

Table 1. Mean percentage of initial moisture content of seeds (IMC); moisture content of the seeds after accelerated aging (AAA); normal seedlings in the germination, accelerated aging and seedling emergence obtained for four seed lots of common bean, cultivar IPR Tuiuiú.

\begin{tabular}{|c|c|c|c|c|c|}
\hline \multirow{3}{*}{ Seed lot } & & & \multicolumn{3}{|c|}{ Tests } \\
\hline & \multicolumn{2}{|c|}{ Moisture content } & \multirow{2}{*}{ Germination } & \multirow{2}{*}{ Accelerated aging } & \multirow{2}{*}{ Seedling emergence } \\
\hline & IMC & AAA & & & \\
\hline \multicolumn{6}{|c|}{ 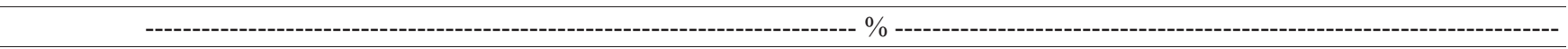 } \\
\hline 1 & 13.8 & 28.0 & $94 \mathrm{a}^{*}$ & $89 \mathrm{a}^{*}$ & $84 \mathrm{a}^{*}$ \\
\hline 2 & 13.5 & 27.0 & $92 \mathrm{ab}$ & $83 \mathrm{~b}$ & $56 \mathrm{bc}$ \\
\hline 3 & 13.5 & 27.5 & $88 \mathrm{bc}$ & $51 \mathrm{~d}$ & $65 \mathrm{~b}$ \\
\hline 4 & 13.0 & 29.0 & $86 \mathrm{c}$ & $76 \mathrm{c}$ & $47 \mathrm{c}$ \\
\hline CV (\%) & - & - & 2.40 & 1.41 & 12.61 \\
\hline
\end{tabular}

*Means followed by same letter in columns do not statistically differ between each other by Tukey test $(\mathrm{p} \leq 0.01)$.

By results achieved on germination test, the seeds from lot 1 showed higher performance than the seeds from the remaining lots. The seeds from lots 2 and 3 were sorted as intermediate quality and the seeds of lot 4 were sorted as lower quality (Table 1). Concerning to vigor, when this variable was assessed by the accelerated aging test, the seeds of lot 1 were also sorted as the most vigorous; the seeds of lots 2 and 4 were sorted as of intermediate performance, and the seeds of lot 3 as the ones with lowest performance (Table 1). The moisture content of seeds has remained within the variation range recommended of until two percentage points (MarcosFilho, 2005), thus assuring the efficiency in test conduction.

Through test of seedling emergence in field, it was possible to show better performance of the seeds from lot 1 in relation to seeds from the remaining lots (Table 1). It was also possible to observe that, for lots 2 and 3, the seeds presented intermediate vigor levels, and that the seeds of lot 4 have been the seeds presenting the lowest vigor; being this classification similar to that obtained by test of germination.

By results obtained in the electrical conductivity test, which was conducted with 4, 8, 16, 20, and 24 h of imbibition periods and under temperatures of $20,25,30$, and $35^{\circ} \mathrm{C}$ (Table 2) it was found that, under the temperature of $20{ }^{\circ} \mathrm{C}$, regardless the imbibition period assessed, the seeds have been sorted in three vigor levels: high (lot 1); intermediate (lot 2); and low (lots 3 and 4).

In a general way, in comparing results obtained under the temperature of $20^{\circ} \mathrm{C}$ (Table 2) with results achieved by test of seedling emergence in field, to all imbibition periods (Table 1), there has been evenness solely in relation superiority of lot 1 (Table 2). Nevertheless, the test was not sufficiently sensitive to 
detect statistically significant differences among seeds of lots 3 and 4 , when assessed by electrical conductivity test. It is worth mentioning that the test of seedling emergence in field showed some consistence in the results to all seed lots assessed, as discussed on Table 1. In this sense, Marcos-Filho (2005) has emphasized that, generally, seeds are conditioned to endure a wide range of environments, thus allowing their classification according to vigor levels.

Table 2. Means values of electrical conductivity of four seed lots of common beans, cv. IPR Tuiuiú, at different temperatures and periods of imbibition.

\begin{tabular}{|c|c|c|c|c|c|}
\hline \multirow{2}{*}{ Seed lot } & \multicolumn{5}{|c|}{ Imbibition periods at $20^{\circ} \mathrm{C}$} \\
\hline & $4 \mathrm{~h}$ & $8 \mathrm{~h}$ & $16 \mathrm{~h}$ & $20 \mathrm{~h}$ & $24 \mathrm{~h}$ \\
\hline & \multicolumn{5}{|c|}{ 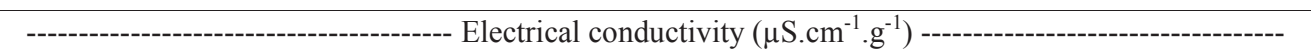 } \\
\hline 1 & $26.3 \mathrm{a}^{*}$ & $37.6 \mathrm{a}^{*}$ & $51.2 \mathrm{a}^{*}$ & $56.1 \mathrm{a}^{*}$ & $60.9 \mathrm{a}^{*}$ \\
\hline 2 & $33.3 \mathrm{~b}$ & $45.4 \mathrm{~b}$ & $62.7 \mathrm{~b}$ & $67.4 \mathrm{~b}$ & $74.5 \mathrm{~b}$ \\
\hline 3 & $39.8 \mathrm{c}$ & $53.0 \mathrm{c}$ & $72.3 \mathrm{c}$ & $77.7 \mathrm{c}$ & $84.4 \mathrm{c}$ \\
\hline 4 & $39.9 \mathrm{c}$ & $56.5 \mathrm{c}$ & $79.2 \mathrm{c}$ & $84.3 \mathrm{c}$ & $92.0 \mathrm{c}$ \\
\hline CV (\%) & 6.51 & 6.49 & 5.45 & 5.25 & 5.12 \\
\hline \multirow{2}{*}{ Seed lot } & \multicolumn{5}{|c|}{ Imbibition periods at $25^{\circ} \mathrm{C}$} \\
\hline & $4 \mathrm{~h}$ & $8 \mathrm{~h}$ & $16 \mathrm{~h}$ & $20 \mathrm{~h}$ & $24 \mathrm{~h}$ \\
\hline & \multicolumn{5}{|c|}{--------------------------------------- Electrical conductivity $\left(\mu \mathrm{S} . \mathrm{cm}^{-1} \cdot \mathrm{g}^{-1}\right)$----------------------------------- } \\
\hline 1 & $34.2 \mathrm{a}$ & $48.3 \mathrm{a}$ & $67.3 \mathrm{a}$ & $72.3 \mathrm{a}$ & $79.5 \mathrm{a}$ \\
\hline 2 & $40.4 \mathrm{~b}$ & $54.7 \mathrm{~b}$ & $89.8 \mathrm{~b}$ & $101.3 \mathrm{~b}$ & $112.2 \mathrm{~b}$ \\
\hline 3 & $50.9 \mathrm{c}$ & $69.1 \mathrm{c}$ & $106.2 \mathrm{c}$ & $112.0 \mathrm{c}$ & $123.6 \mathrm{c}$ \\
\hline 4 & $53.7 \mathrm{c}$ & $76.9 \mathrm{~d}$ & $106.6 \mathrm{c}$ & $123.3 \mathrm{~d}$ & $135.5 \mathrm{~d}$ \\
\hline $\mathrm{CV}(\%)$ & 5.8 & 3.86 & 3.69 & 3.13 & 3.79 \\
\hline \multirow{2}{*}{ Seed lot } & \multicolumn{5}{|c|}{ Imbibition periods at $30^{\circ} \mathrm{C}$} \\
\hline & $4 \mathrm{~h}$ & $8 \mathrm{~h}$ & $16 \mathrm{~h}$ & $20 \mathrm{~h}$ & $24 \mathrm{~h}$ \\
\hline & \multicolumn{5}{|c|}{ 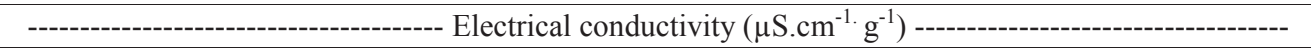 } \\
\hline 1 & $40.4 \mathrm{a}$ & $56.7 \mathrm{a}$ & $69.3 \mathrm{a}$ & $79.3 \mathrm{a}$ & $97.7 \mathrm{a}$ \\
\hline 2 & $48.2 \mathrm{~b}$ & $67.3 \mathrm{~b}$ & $91.2 \mathrm{~b}$ & $107.7 \mathrm{~b}$ & $130.3 \mathrm{~b}$ \\
\hline 3 & $67.2 \mathrm{~d}$ & $89.6 \mathrm{c}$ & $110.0 \mathrm{c}$ & $122.2 \mathrm{c}$ & $159.2 \mathrm{c}$ \\
\hline 4 & $58.1 \mathrm{c}$ & $84.3 \mathrm{c}$ & $107.0 \mathrm{c}$ & $125.7 \mathrm{c}$ & $155.0 \mathrm{c}$ \\
\hline $\mathrm{CV}(\%)$ & 4.14 & 4.51 & 4.55 & 4.61 & 5.20 \\
\hline \multirow{3}{*}{ Seed lot } & \multicolumn{5}{|c|}{ Imbibition periods at $35^{\circ} \mathrm{C}$} \\
\hline & $4 \mathrm{~h}$ & $8 \mathrm{~h}$ & $16 \mathrm{~h}$ & $20 \mathrm{~h}$ & $24 \mathrm{~h}$ \\
\hline & \multicolumn{5}{|c|}{ 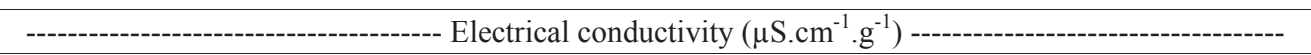 } \\
\hline 1 & $39.5 \mathrm{a}$ & $60.6 \mathrm{a}$ & $79.3 \mathrm{a}$ & $92.9 \mathrm{a}$ & $107.8 \mathrm{a}$ \\
\hline 2 & $47.7 \mathrm{~b}$ & $69.1 \mathrm{a}$ & $108.0 \mathrm{~b}$ & $126.5 \mathrm{~b}$ & $135.4 \mathrm{~b}$ \\
\hline 3 & $63.8 \mathrm{c}$ & $99.4 \mathrm{~b}$ & $138.1 \mathrm{c}$ & $168.7 \mathrm{c}$ & $215.5 \mathrm{~d}$ \\
\hline 4 & $70.9 \mathrm{~d}$ & $96.4 \mathrm{~b}$ & $131.5 \mathrm{c}$ & $153.5 \mathrm{c}$ & $181.4 \mathrm{c}$ \\
\hline CV (\%) & 5.95 & 6.46 & 8.77 & 7.32 & 6.98 \\
\hline
\end{tabular}

*Means followed by same letter in columns do not statistically differ between each other by Tukey test $(\mathrm{p} \leq 0.01)$.

To certify efficiency of a vigor test it is recommended that values of results obtained for this variable are close to values obtained for emergence of seedlings in field. This way, the aim of the test would be estimating the behavior of the seeds from different lots, after the sowing of those seeds in different environmental conditions (Ilbi et al., 2009; Marcos-Filho and Novembre, 2009).

As previously discussed, it was observed that when the electrical conductivity test was conducted at $25^{\circ} \mathrm{C}$ and starting from the imbibition period of $20 \mathrm{~h}$, were found results similar to results obtained for emergence of seedlings in field (Table 1), and so, the seeds of lot 1 were sorted as the most vigorous, the seeds of lots 2 and 3 with an intermediary vigor, and the seeds of lot 4 as the less vigorous ones (Table 2). An identical ranking was maintained after $24 \mathrm{~h}$ imbibition period, thus demonstrating methodology efficiency. Such fact is relevant because the electrical conductivity test simulates the behavior results that can affect the vigor of the seeds in its establishment of seedling in field (Comiotto et al., 2011). 
It is worth mentioning that the combination of $25^{\circ} \mathrm{C}$ temperature with an imbibition period of $24 \mathrm{~h}$, already was successfully used to other species of Fabaceae such as: soybean (Hampton and TeKrony, 1995; Vieira and Krzyzanowski, 1999; Santos et al., 2011) and peanuts (Arachis hypogaea L.) (Barbosa et al., 2012).

With the increase on the conditioning temperature to $30{ }^{\circ} \mathrm{C}$ (Table 2) it has been found that there has been higher release of exudates, in relation to temperature of $25{ }^{\circ} \mathrm{C}$, and that the test of electrical conductivity has established a ranking for the lots well different from ranking observed for emergence of seedlings in field as previously discussed; and so has not detected statistically significant differences for quality of the seeds originating from seed lots 3 and 4. Similar results were obtained by Albuquerque et al. (2001) in a study with sunflower seeds (Helianthus annuus L.) in which it was detected that the high incubation temperature of $30{ }^{\circ} \mathrm{C}$ caused a significantly higher release of electrolytes into imbibition solution in relation to temperature of $25^{\circ} \mathrm{C}$.

Within this study, results of this test were likewise unsatisfactory when incubation was performed at temperature of $35^{\circ} \mathrm{C}$ (Table 2), once the test was not sufficiently sensitive to detect statistically significant differences between seed lots 3 and 4 and the seeds were then sorted as bearing the lowest physiological potential; what does not coincide with the results obtained for emergence of seedlings in field, as previously discussed. This response has probably occurred in function of release of higher amounts of leachates into the imbibition solution, due to smaller structuring and selectivity of cellular membranes, as previously reported by Vieira and Krzyzanowski (1999).

In a general way, in observing data achieved by test of electrical conductivity (Table 2 ) it is possible observing that, at the temperatures $30{ }^{\circ} \mathrm{C}$ and $35^{\circ} \mathrm{C}$, and as the imbibition periods were gradually increasing from 4 until $24 \mathrm{~h}$, the values obtained were also increasing; clearly showing there was a higher release of exudates into the seed imbibition solution. This event may be related to the temperature increase at the moment of seed incubation, once temperatures above $30{ }^{\circ} \mathrm{C}$ can influence water absorption speed (Taiz and Zeiger, 2004) and consequently increase the amount of solutes leached by the seeds into the imbibition solution.

For soybean seeds, Carvalho et al. (2009a) have found that the increase on temperature during the seed imbibition process for test of electrical conductivity, decreases seed conditioning period for the identification of vigor levels. However, the results herein achieved have not demonstrated the same efficiency of this test in assessing common beans seeds when the temperature is increased beyond $30^{\circ} \mathrm{C}$ (Table 2).

In this context, the combinations of $25{ }^{\circ} \mathrm{C} \times 20 \mathrm{~h}$ of imbibition as well as of $25{ }^{\circ} \mathrm{C} \times 24 \mathrm{~h}$ of imbibition, have shown to be adequate for conducting the electrical conductivity test, once results have demonstrated a behavior similar to the results found for emergence of seedlings in field. It is worth mentioning that by the easiness in the routine analyses in seed testing laboratories, the soaking of seeds during $24 \mathrm{~h}$ has have been the most recommended (Vieira and Krzyzanowski, 1999). In addition, the temperature of $25^{\circ} \mathrm{C}$ is fairly promising for conduction of this test, since it is closest to the environmental conditions found in majority of the seed testing laboratories in Brazil.

\section{Phase II - Genotype effects}

\section{$A$ - Results for the trade group Carioca}

Results obtained for seed quality of the cv. IPR 139 and cv. IPR Juriti are presented on Table 3. Through these data, it is possible to observe that values for the initial moisture content of seeds were similar between the different seed lots, which have presented maximum variation of 0.4 (cv. IPR 139) and 0.7 (cv. IPR Juriti) percentage points. Another important aspect is that a moisture contents very low $(\geq 10)$, as well as a moisture contents very high $(\leq 17)$ have influence on electrical conductivity test results (Vieira et al., 2002). Nevertheless, by results herein obtained for moisture content, the common bean seeds were within the recommended range, i.e., around 13\% (Table 3).

As for the seeds of cultivar IPR 139, the germination percentage has allowed sorting seed lots as high quality (lots 5 and 6) and low quality (lots 7 and 8). By the accelerated aging test and emergence of seedling in field, which provide data on the seed vigor, allowed the seed lots were considered of high vigor (lot 5), intermediate vigor (lot 6), and of low vigor (lots 7 and 8) (Table 3). Concerning seed quality, on analyzing results of electrical conductivity test, it was found similarities with results obtained in the tests of germination, accelerated aging, and emergence of seedling in field in relation to the sorting of the lots, thus allowing the differentiation between the lots with lower vigor (lots 7 and 8 ) from the other two lots (lots 5 and 6), indicating that test was efficient in estimating physiological potential of the seeds of this common bean cultivar.

Through results achieved in the test of germination, when this was carried out with seeds of cv. IPR Juriti (Table 3), it is possible observing that the seed lots 9 and 10 have presented higher germination percentage, indicating that seeds of these two lots have had higher physiological quality than the seeds originating from lots 11 and 12, which were then sorted as bearing low quality. Similar results were found for accelerated aging test. Nevertheless, in the test of seedling emergence in 
field, the method revealed higher sensitivity in distinguishing the quality among seed lots, this way allowing that the lots 9 and 10 were sorted as having the best performance in field and the lots 11 and 12 as bearing intermediate and low quality, respectively.

Table 3. Means values for the initial moisture content of seeds (IMC) and moisture content of seeds after the accelerated aging test (AAA); germination, accelerated aging, seedling emergence in field, electrical conductivity obtained for four seed lots of common beans, cv. IPR 139 and cv. IPR Juriti, belonging to trade group Carioca.

\begin{tabular}{|c|c|c|c|c|c|c|}
\hline & \multicolumn{6}{|c|}{ Tests } \\
\hline Cv IPR 139 & \multicolumn{2}{|c|}{ Moisture content } & \multirow{2}{*}{ Germination } & \multirow{2}{*}{ Accelerated aging } & \multirow{2}{*}{ Seedling emergence } & \multirow{2}{*}{ Electrical conductivity } \\
\hline Lot & IMC & AAA & & & & \\
\hline & \multicolumn{5}{|c|}{ 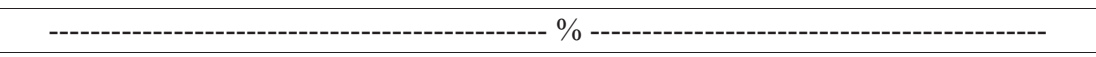 } & $\mu \mathrm{S} . \mathrm{cm}^{-1} \cdot \mathrm{g}^{-1}$ \\
\hline 5 & 13.4 & $30.0^{*}$ & $95 a^{*}$ & $82 a^{*}$ & $91 \mathrm{a}^{*}$ & $93.4 \mathrm{ab}^{*}$ \\
\hline 6 & 13.8 & 29.0 & $93 \mathrm{a}$ & $67 \mathrm{~b}$ & $88 \mathrm{ab}$ & $91.7 \mathrm{a}$ \\
\hline 7 & 13.8 & 29.0 & $86 \mathrm{~b}$ & $57 \mathrm{c}$ & $80 \mathrm{~b}$ & 119. b \\
\hline 8 & 13.5 & 31.0 & $84 \mathrm{~b}$ & $58 \mathrm{c}$ & $83 \mathrm{~b}$ & $123.8 \mathrm{~b}$ \\
\hline CV (\%) & - & - & 3.68 & 4.85 & 4.64 & 6.12 \\
\hline Cv IPR Juriti & \multicolumn{2}{|c|}{ Moisture content } & Germination & A coolerated a oring & Seedling emeronence & Electrical conductivity \\
\hline \multirow[t]{2}{*}{ Lot } & IMC & AAA & Germmation & Accererated agmg & seeding emergence & Electricar conauctivity \\
\hline & \multicolumn{5}{|c|}{ 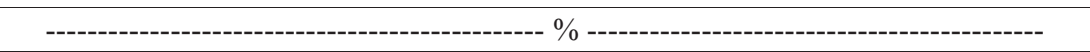 } & $\mu \mathrm{S} . \mathrm{cm}^{-1} \cdot \mathrm{g}^{-1}$ \\
\hline 9 & 14.5 & 30.0 & $95 \mathrm{a}$ & $84 \mathrm{a}$ & $94 \mathrm{a}$ & $64.8 \mathrm{a}$ \\
\hline 10 & 14.8 & 31.0 & $93 \mathrm{a}$ & $85 \mathrm{a}$ & $92 \mathrm{a}$ & $68.0 \mathrm{a}$ \\
\hline 11 & 14.5 & 29.0 & $83 \mathrm{~b}$ & $53 \mathrm{~b}$ & $82 \mathrm{~b}$ & $137.3 \mathrm{~b}$ \\
\hline 12 & 14.1 & 29.0 & $80 \mathrm{~b}$ & $51 \mathrm{~b}$ & $71 \mathrm{c}$ & $131.8 \mathrm{~b}$ \\
\hline CV (\%) & - & - & 1.99 & 3.94 & 5.22 & 5.72 \\
\hline
\end{tabular}

*Means followed by same letter in columns do not statistically differ between each other by Tukey test $(\mathrm{p} \leq 0.01)$.

Wrasse et al. (2009) have identified that seeds with low physiological potential have lower performance as much under laboratory conditions as in field conditions. Within this study, when results obtained by electrical conductivity test are examined, it is possible to verify that these results present similarities with results obtained in other tests of seed physiological quality. In this manner allowing ranking the seeds of lots 9 and 10 as the most vigorous ones and the seeds of lots 11 and 12 as possessing lower vigor (Table 3). In a study with soybean seeds, Carvalho et al. (2009b) have found that results of the electrical conductivity test were correlated with the results of other tests of vigor such as: germination; accelerated aging; and seedling emergence in sand.

Thus, it was possible to verify efficiency of electrical conductivity test, for seeds of the two common bean cultivars belonging to the trade group Carioca, only when the test was carried out at $25{ }^{\circ} \mathrm{C}$ temperature and a soaking period of $24 \mathrm{~h}$ for conditioning; but, without allowing the detection of the influence of genotype on test results. Nonetheless, these results differ from those results achieved by Vieira et al. (1996), who have reported that the results for vigor of common bean seeds are very expressively influenced by the genotype factor, when these seeds are assessed by the test of electrical conductivity.

\section{$B$ - Results for the trade group Black}

Data referring to the moisture content of seeds of the cv. IPR Gralha and cv. BRS Campeiro, assessed before and after the accelerated aging test, as well as data of the tests of: germination; accelerated aging; seedling emergence in field; and electrical conductivity are presented on Table 4. Through these data it is possible to verify that the values for initial moisture content of seeds were similar, with maximum variation of 0.5 percentage points for $\mathrm{cv}$. IPR Gralha and 1.0 percentage points for cv. BRS Campeiro. However, when the moisture content of the seeds was assessed after the accelerated aging test, these seeds presented a maximum variation of 1.5 percentage points for the moisture content (Table 4).

It is worth mentioning that the knowledge of moisture content is important for performing seed assessment tests, once the use of a pattern of moisture is indispensable for the reliability in the results of the assessments (Marcos-Filho, 2005); and that data obtained for the moisture content (Table 4) also have agreed with what has been proposed by Vieira et al. (2002) for conducting the electrical conductivity test. The influence of moisture content of seeds, before conducting the electrical conductivity test, already was the target of a study with seeds of peanuts (Arachis hypogaea L.), where there would be 
stabilization of the referred test when the seeds had moisture content between 10.0\% and 14.0\% (Barbosa et al., 2012).

Table 4. Means values for the initial moisture content of seeds (IMC) and moisture content of seeds after the accelerated aging test (AAA); germination, accelerated aging, seedling emergence, electrical conductivity obtained for four seed lots of common beans, cv. IPR Gralha and cv. BRS Campeiro, belonging to trade group Preto.

\begin{tabular}{|c|c|c|c|c|c|c|}
\hline \multicolumn{7}{|c|}{ Tests } \\
\hline Cv. IPR Gralha & \multicolumn{2}{|c|}{ Moisture content } & \multirow{2}{*}{ Germination } & \multirow{2}{*}{ Accelerated aging } & \multirow{2}{*}{ Seedling emergence } & \multirow{2}{*}{ Electrical conductivity } \\
\hline Lot & IMC & AAA & & & & \\
\hline & \multicolumn{5}{|c|}{-------------------------------------------- } & $\mu \mathrm{S} . \mathrm{cm}^{-1} \cdot \mathrm{g}^{-1}$ \\
\hline 13 & 12.5 & 29.0 & $91 a^{*}$ & $68 a^{*}$ & $92 a^{*}$ & $117.1 \mathrm{a}^{*}$ \\
\hline 14 & 12.5 & 29.8 & $90 \mathrm{a}$ & $62 \mathrm{~b}$ & $86 \mathrm{~b}$ & $125.1 \mathrm{a}$ \\
\hline 15 & 12.0 & 28.5 & $80 \mathrm{~b}$ & $57 \mathrm{~b}$ & $79 \mathrm{c}$ & $116.3 \mathrm{a}$ \\
\hline 16 & 12.5 & 28.5 & $80 \mathrm{~b}$ & $61 \mathrm{~b}$ & $78 \mathrm{c}$ & $111.5 \mathrm{a}$ \\
\hline $\mathrm{CV}(\%)$ & - & - & 3.22 & 3.41 & 2.58 & 6.00 \\
\hline Cv. BRS Campeiro & \multicolumn{2}{|c|}{ Moisture content } & Germination & A ccelerated aoing & Seedling emercence & Flectricl conductivity \\
\hline \multirow[t]{2}{*}{ Lot } & IMC & AAA & Serimintariont & ACecicialed aging & 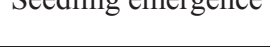 & Liectitcar concuctivity \\
\hline & \multicolumn{5}{|c|}{ 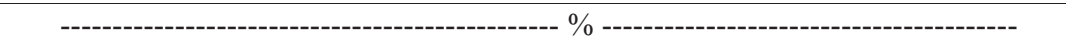 } & $\mu$ S.cm ${ }^{-1} \cdot \mathrm{g}^{-1}$ \\
\hline 17 & 13.0 & 28.0 & $97 \mathrm{a}$ & $88 \mathrm{a}$ & $88 \mathrm{a}$ & $109.6 \mathrm{c}$ \\
\hline 18 & 12.5 & 27.0 & $94 \mathrm{~b}$ & $80 \mathrm{bc}$ & $89 \mathrm{a}$ & $95.8 \mathrm{~b}$ \\
\hline 19 & 12.0 & 26.5 & $90 \mathrm{c}$ & $77 \mathrm{c}$ & $80 \mathrm{~b}$ & $81.9 \mathrm{a}$ \\
\hline 20 & 12.0 & 27.0 & $81 \mathrm{~d}$ & $81 \mathrm{~b}$ & $73 \mathrm{c}$ & $72.0 \mathrm{a}$ \\
\hline $\mathrm{CV}(\%)$ & - & - & 1.66 & 1.89 & 2.91 & 7.00 \\
\hline
\end{tabular}

* Means followed by same letter in columns do not statistically differ between each other by Tukey test $(\mathrm{p} \leq 0.01)$.

The mean of data obtained for germination of the seeds of common beans, cv. IPR Gralha (Table 4) have allowed sorting lots 13 and 14, as of high physiological quality and the lots 15 and 16, as of low physiological quality. However, through the data obtained in the accelerated aging test, the seeds of lots 14,15 , and 16 can be classified as the least vigorous ones and the seeds of lot 13 as of the best vigor ones. When the assessment was performed by test of seedling emergence in field, it was observed a larger sensitivity in distinguishing the physiological quality of the seeds among the different lots; thus making possible to classify lots 16 and 15 as of the worst performance ones, the lot 14 as of intermediate performance, and lot 13 as the one with the best performance in the field.

In contrast, it was not possible separating the seed lots in different vigor levels by the test electrical conductivity (Table 4). Therefore, the means obtained for the seeds of the lots classified as of low performance by the tests of germination, accelerated aging, and seedling emergence in field (lots 15 and 16) were not statistically different from the means obtained for lots 13 and 14. As highlighted by Schuab et al. (2006), it is necessary that results achieved through this test have similarity with results obtained by the test of seedling emergence in field, once climatic conditions prevailing in the field are quite variable.

By the means obtained for germination of the seeds of the cv. BRS Campeiro, it can be seen that the seeds of this cultivar have presented differences in physiological quality; once the seeds of lot 17 have presented the highest values for germination (97\%), lots 18 and 19 have presented intermediate germination ( $94 \%$ and $90 \%$, respectively), and the lot 20 has presented the lowest values for physiological quality (81\%) (Table 4$)$.

Through the means computed from the data obtained after accelerated aging test (Table 4), the seeds of lot 17 have shown the highest vigor level (88\%), the seeds of lots 18 and 20 have shown an intermediary vigor level ( $80 \%$ and $81 \%$ respectively) and the seeds of lot 19 have shown the lowest vigor level (77\%). Nevertheless, through the means obtained by the seedling emergence in field, the seeds from lots 17 and 18 were sorted as the most vigorous ones ( $88 \%$ and $89 \%$ emergence, respectively), the seeds from lot 19 were classified as having intermediate level of vigor $(80 \%)$, and the seeds from lot 20 as having the worst vigor level (73\%) (Table 4).

When the means obtained by the electrical conductivity test are examined, it is possible to verify that the seeds from the lots that have revealed lower performance, when assessed by the tests of germination, accelerated aging, and seedling emergence in field, i.e. lots 19 and 20, were the ones that have presented with the smallest amount of electrolytes released into the imbibition solution, allowing to classify them as the seeds with the lowest vigor (Table 4). However, the seeds of lot 17 , which were considered as of the highest quality when 
assessed by the previously mentioned tests, showed that seeds had actually released higher amounts of electrolytes in the soaking solution, and therefore were considered as the ones that have had the lowest vigor.

The results herein obtained corroborates results attained by Vieira et al. (1996), who in a study with common bean seeds have observed influence of genotype in the results of electrical conductivity test. The same authors have also verified that the seeds of some cultivars, which have presented high performance by the tests of germination and accelerated aging, were sorted as of low vigor by electrical conductivity test; although the inverse has also been observed.

In the literature are found reports of studies that were carried out with seeds of sunflower (Albuquerque et al., 2001), tobacco (Nicotiana tabacum L.) (Carvalho and Novembre, 2011), and Scarlet eggplant (Solanum gilo Raddi.; syn. Solanum aethiopicum L.) (Lopes et al., 2012), and have shown that electrical conductivity test was little efficient on evaluating seed quality of these species. Albuquerque et al. (2001) have found differences on results obtained by electrical conductivity test among seeds of different sunflower genotypes by them assessed, what allowed the inversion of the sorting of these genotypes in relation to seed physiological quality obtained by other assessment tests; however, there are still paucity of studies concerning the reasons that leads to these divergences.

Such results may be related to chemical composition of the seed coat of these seeds. This event has already been detected by Santos et al. (2007), who have observed that seeds of soybean cultivars that have brown seed coat may have the results of electrical conductivity test affected, once this tegument type presents higher contents of lignin and protein, what leads to a smaller imbibition speed. In addition, hereditary characteristics, such as thickness and lignin content of the seed coat are the factors liable by the differences of vigor among genotypes (Vieira and Krzyzanowski, 1999). In this sense, the lowest values for electrical conductivity may be linked to higher content of lignin on the seed coat, as already found by Panobianco et al. (1999).

From data obtained within the present study, it is possible to conclude that the electrical conductivity test can be used for distinction of vigor levels among seeds of different common beans lots, when this test is carried out with samples of 50 seeds each, which should be imbibed in $75 \mathrm{~mL}$ deionized water, incubated at $25{ }^{\circ} \mathrm{C}$, during a period of 20 or $24 \mathrm{~h}$ for conditioning and with values of electrical conductivity measured with aid of a digital conductivimeter that provides a direct reading as $\mu \mathrm{S} . \mathrm{cm}^{-1} \cdot \mathrm{g}^{-1}$. In these combinations of temperature $\mathrm{x}$ conditioning period, it is possible to obtain results similar to the results obtained for seedling emergence in field.
In addition, it is worth emphasizing that the $24 \mathrm{~h}$ imbibition period for the conditioning of the seeds to the electrical conductivity test is very appropriate for routine analyses in the seed testing laboratories; besides to be indicated for vigor analysis of seeds of other species of plants of economical importance (Hampton and TeKrony, 1995; Vieira and Krzyzanowski, 1999; Santos et al., 2011; Barbosa et al., 2012).

However, regarding the appropriateness of the methodology of the electrical conductivity test, for specific use in evaluating seeds of common beans, as well as to detect the effect of genotype in the results obtained by this test, are still needed additional and more detailed studies to elucidate the physiological and biochemical mechanisms involved in the changes in the amount of electrolytes released from the seeds by leaching and then scattered in the imbibition solution.

\section{Conclusions}

To evaluate vigor of common bean seeds, the electrical conductivity test should be conducted with four replications of 50 seeds each soaked in a volume of $75 \mathrm{~mL}$ of deionized water, at $25^{\circ} \mathrm{C}$, for 24 hours.

The efficiency of electrical conductivity test is variable according to cultivar assessed; however, for the trade group Carioca there is not genotype influence in the results obtained in the test; but the same does not occur for the results obtained for the trade group Black.

\section{References}

ALBUQUERQUE, M.C.F.E.; MORO, F.V.; FAGIOLI, M.; RIBEIRO, M. C. Testes de condutividade elétrica e de lixiviação de potássio na avaliação de qualidade fisiológica de sementes de girassol. Revista Brasileira de Sementes, v.23, n.1, p.1-8, 2001. http://www.abrates.org.br/revista/artigos/2001/v23n1/artigo01.pdf

ARAÚJO, R.F.; ZONTA, J.B., ARAÚJO, E.F.; HEBERLE, E.; ZONTA, F.M.G. Teste de condutividade elétrica para sementes de feijão-mungo-verde. Revista Brasileira de Sementes, v.33, n.1 p.123-130, 2011. http://www.scielo.

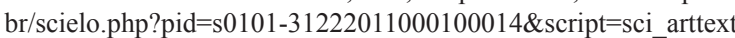

BARBOSA, R.M.; SILVA, C.B.; MEDEIROS, M.A.; CENTURIOM, M.A.P.C.; VIEIRA, R.D. Condutividade elétrica em função do teor de água inicial de sementes de amendoim. Ciência Rural, v.42, n.1, p.45-51, 2012. http://www.scielo.br/pdf/cr/v42n1/a0812cr4615.pdf

BOTELHO, F.J.E.; GUIMARÃES, R.M.; OLIVEIRA, J.A.; EVANGELISTA, J.R.E.; ELOI, T.A.; BALIZA, D.P. Desempenho fisiológico de sementes de feijão colhidas em diferentes períodos de desenvolvimento. Ciência e Agrotecnologia, v.34, n.4, p.900-907, 2010. http://www.scielo.br/scielo. php?pid=s1413-70542010000400015\&script=sci_arttext

BRASIL. Ministério da Agricultura, Pecuária e Abastecimento. Regras para análise de sementes. Ministério da Agricultura, Pecuária e Abastecimento. Secretaria de Defesa Agropecuária. Brasília, DF: MAPA/ACS, 2009. 395p. http://www.agricultura.gov.br/arq editor/file/laborat\%c3\%b3rio/sementes/ regras $\% 20$ para $\% 20$ analise $\% 20 \mathrm{de} \% 20$ sementes.pdf 
CARVALHO, C.; NOVEMBRE, A.D.L.C. Avaliação da qualidade de sementes de fumo, nuas e revestidas, pelo teste de condutividade elétrica. Revista Brasileira de Sementes, v.33, n.1 p.177-185, 2011. http://www.scielo. br/scielo.php?pid=s0101-31222011000100020\&script=sci arttext

CARVALHO, L.F.; SEDIYAMA, C.S.; REIS, M.S.; DIAS, D.C.F.S.; MOREIRA, M.A. Influência da temperatura de embebição da semente de soja no teste de condutividade elétrica para avaliação da qualidade fisiológica. Revista Brasileira de Sementes, v.31, n.1, p.9-17, 2009a. http://www.scielo. $\mathrm{br} / \mathrm{pdf} / \mathrm{rbs} / \mathrm{v} 31 \mathrm{n} 1 / \mathrm{a} 01 \mathrm{v} 31 \mathrm{n} 1 . \mathrm{pdf}$

CARVALHO, L.F.; SEDIYAMA, C.S.; DIAS, D.C.F.S.; REIS, M.S.; MOREIRA, M.A. Teste rápido de condutividade elétrica e correlação com outros testes de vigor. Revista Brasileira de Sementes, v.31, n.1, p.239-248, 2009b. http://www.scielo.br/pdf/rbs/v31n1/a27v31n1.pdf

COELHO, C.M.M.; MOTA, M.R.; SOUZA, C.A.; MIQUELLUTI, D.J. Potencial fisiológico em sementes de cultivares de feijão crioulo (Phaseolus vulgaris L.). Revista Brasileira de Sementes, v.32, n.3 p.97-105, 2010. http:// www.scielo.br/pdf/rbs/v32n3/v32n3a11.pdf

COMIOTTO, A.; MORAES, D.M.; LOPES, N.F. Potencial alelopático de extratos aquosos de aroeira sobre germinação e crescimento de plântulas de alface. Scientia Agraria Paranaensis, v.10, n.3, p 23-31, 2011. http://erevista.unioeste.br/index.php/scientiaagraria/article/view/4349

DUTRA, A.; VIEIRA, R.D. Teste de condutividade elétrica para a avaliação do vigor de sementes de abobrinha. Revista Brasileira de Sementes, v.28, n.2, p.117-122, 2006. http://www.scielo.br/pdf/rbs/v28n2/a15v28n2.pdf

HAMPTON, J.G.; TEKRONY, D.M. Controlled deterioration test. In: HAMPTON AND TEKRONY (Ed). Handbook of vigour test methods. Zurich: ISTA, p.70-78, 1995

ILBI, H.; KAVAK, S.; ESER, B. Cool germination test can be an alternative vigour test for maize. Seed Science and Technology, v.37, n.2, p.516-519, 2009.

LOPES, M.M.; BARBOSA, R.M.; VIEIRA, R.D. Methods for evaluating the physiological potential of Scarlet eggplant (Solanum aethiopicum) seeds. Seed Science and Technology, v.40, n.1, p.86-94, 2012.

MACHADO, C.G.; MARTIND, C.C.; SANTANA, D.G.; CRUZ, S.C.S.; OLIVEIRA, S.S.C. Adequação do teste de condutividade elétrica para sementes de Pisum sativum subsp. Arvense. Ciência Rural, v.41, n.6, p.988-995, 2011. http:// www.scielo.br/scielo.php?pid=S0103-4782011000600012\&script=sci arttext

MARCOS-FILHO, J. Fisiologia de sementes de plantas cultivadas. Piracicaba: FEALQ, 2005. 495p.

MARCOS-FILHO, J.; NOVEMBRE, A.D.L.C. Avaliação do potencial fisiológico de sementes de hortaliças. In: NASCIMENTO, W.M. (Ed.). Tecnologia de sementes de hortaliças. Brasília, DF: Embrapa Hortaliças, 2009. p.185-246.

MENEZES, N.L.; GARCIA, D.C.; BAHRY, C.A.; MATTIONI, N.M. Teste de condutividade elétrica em sementes de aveia preta. Revista Brasileira de Sementes, v.29, n.2, p.138-142, 2007. http://www.scielo.br/pdf/rbs/v29n2/v29n2a19.pdf

OLIVEIRA, S.R.S.; NOVEMBRE, A.D.L.C. Teste de condutividade elétrica para as sementes de pimentão. Revista Brasileira de Sementes, v.27, n.1, p.31-36, 2005. http://www.scielo.br/pdf/rbs/v27n1/25178.pdf

PANOBIANCO, M.; VIEIRA, R.D.; KRZYZANOWSKI, F.C.; FRANCANETO, J.B. Electrical conductivity of soybean seed and correlation with seed coat lignina contente. Seed Science Technology, v.27, p.945-949, 1999.

SANTOS, C.M.R.; MENEZES, N.L.; VILLELA, F.A. Teste de deterioração controlada para avaliação do vigor de sementes de feijão. Revista Brasileira de Sementes, v.25, n.2, p.28-35, 2003. http://www.abrates.org.br/revista/artigos/2003/ v25n2/artigo05.pdf
SANTOS, C.M.R.; MENEZES, N.L.; VILLELA, F.A. Alterações fisiológicas e bioquímicas em sementes de feijão envelhecidas artificialmente. Revista Brasileira de Sementes, v.26, n.1, p.110-119, 2004. http://www.scielo.br/pdf/ rbs/v26n1/a17v26n1.pdf

SANTOS， C.M.R.; MENEZES， N.L.; VILLELA，F.A. Modificações fisiológicas e bioquímicas em sementes de feijão no armazenamento. Revista Brasileira de Sementes, v.27, n.1, p.104-114, 2005. http://www.scielo.br/ scielo.php?script=sci_arttext\&pid=s0101-31222005000100013

SANTOS, E.L.; PÓLA, J.N.; BARROS, A.S.R.; PRETE, C.E.C. Qualidade fisiológica e composição química das sementes de soja com variação na cor do tegumento. Revista Brasileira de Sementes, v.29, n.1, p.20-26, 2007. http://www. scielo.br/scielo.php?script=sci arttext\&pid=S0101-31222007000100003

SANTOS, J.F.; ALVARENGA, R.O.; TIMÓTEO, T.S.; CONFORTO, E.C.; MARCOS FILHO, J.; VIEIRA, R. D. Avaliação do potencial fisiológico de lotes de sementes de soja. Revista Brasileira de Sementes, v.33, n.4, p.743-751, 2011. http:// www.scielo.br/scielo.php?pid=s0101-31222011000400016\&script=sci_arttext

SCHUAB, S.R.P.; BRACCINI, A.L.B.; FRANCA-NETO, J.B.; SCAPIM, C.A.; MESCHEDE, D.K. Potencial fisiológico de sementes de soja e sua relação com a emergência das plântulas em campo. Acta Scientiaru Agronomy, v.28, n.4, p.553-561, 2006.

SOARES, M.M.; CONCEIČ̃̃O, P.M.; DIAS, D.C.F.S.; ALVARENGA, E.M. Testes para avaliação do vigor de sementes de sorgo comênfase à condutividade elétrica. Ciência e Agrotecnologia, v.34, n.2, p.391-397, 2010. http://www. scielo.br/scielo.php?pid=S1413-70542010000200017\&script=sci_arttext

SOUZA, L.A.; CARVALHO, M.L.M.; KATAOKA, V.Y.; OLIVEIRA, J.A. Teste de condutividade elétrica para avaliação da qualidade fisiológica de sementes de mamona. Revista Brasileira de Sementes, v.31, n.1, p.60-67, 2009. http://www.scielo.br/pdf/rbs/v31n1/a07v31n1.pdf

TAIZ, L.; ZEIGER, E. Fisiologia Vegetal. 3.ed. Porto Alegre: Artmed, 2004. 719p.

VIDIGAL, D.S.; LIMA, J.S.; BHERING, M.C.; DIAS, D.C.F.S. Teste de condutividade elétrica para semente de pimenta. Revista Brasileira de Sementes, v.30, n.1, p.168-174, 2008. http://www.scielo.br/pdf/rbs/v30n1/a21v30n1.pdf

VIEIRA, R.D.; PANOBIANCO, M.; LEMOS, L.B.; FORNASIERI-FILHO, D.; Efeito de genótipos de feijão e de soja sobre os resultados da condutividade elétrica de sementes. Revista Brasileira de Sementes, v.18, n.2, p.220-224, 1996.

VIEIRA, R.D.; KRZYZANOWSKI, F.C. Teste de condutividade elétrica. In VIEIRA, R.D.; KRZYZANOWSKI, F.C.; FRANCCA-NETO, J.B. Vigor de sementes: conceitos e testes. Londrina: ABRATES, Cap.4, p.1-26, 1999.

VIEIRA, R.D.; PENARIOL, A.L.; PERECIN, D.; PANOBIANCO, M Condutividade elétrica e o teor de água inicial das sementes de soja. Pesquisa Agropecuária Brasileira, v.37, n.19, p.1333-1338, 2002. http://www.scielo.br/pdf/ $\mathrm{pab} / \mathrm{v} 37 \mathrm{n} 9 / 13209 . \mathrm{pdf}$

VIEIRA, R.D.; SCAPPANETO,A.; BITTENCOURT, S.R.M.; PANOBIANCO, $\mathrm{M}$. Electrical conductivity of the seed soaking solution and soybean seedling emergence. Scientia Agricola, v.61, n.2, p.164-168, 2004. http://www.scielo.br/ scielo.php?pid=S0103-90162004000200007\&script=sci_arttext

VIEIRA, R.D; DUTRA, A.S. Condutividade elétrica em sementes de abóbora, híbrido Bárbara. Horticultura Brasileira, v.24, n.3, p.305-308, 2006. http://www.scielo.br/pdf/hb/v24n3/07.pdf

WRASSE, C.F.; MENEZES, N.L.; MARCHESAN, E.; VILLELA, F.A.; BORTOLOTTO, R.P. Testes de vigor para sementes de arroz e sua relação com o comportamentode hidrataçãodesementesea emergência deplântulas.Científica, v.37, n.2, p.107-114, 2009. http://www.scielo.br/scielo.php?script=sci nlinks\&ref $=000087 \&$ pid $=$ s01013122201200010001300025\&lng=en 